\title{
Assessment of lignocellulosic residues from Northern Patagonian Andes (Argentina) for cultivation of Pleurotus ostreatus
}

\author{
Juan Manuel Roggero Luque ${ }^{1,2,4}$, Maximiliano Rugolo*1,2,4, Mario Rajchenberg ${ }^{1,2,3}$, Carolina \\ Barroetaveña ${ }^{1,2,3}$
}

\section{Edited by}

Juan Carlos Salcedo-Reyes

salcedo.juan@javeriana.edu.co

1. Centro de Investigación y Extensión Forestal Andino Patagónico, route 259, km 16.24 (9200), Esquel (Chubut), Argentina.

2. Consejo Nacional de Investigaciones Científicas y Técnicas (CONICET), Argentina.

3. Universidad Nacional de la Patagonia San Juan Bosco, Fac. Ingeniería, sede Esquel, Argentina.

4. Authors who have contributed equally to this study and share the position of first author (ex aequo).

*maxirugolo@gmail.com

Received: $30-04-2020$

Accepted: 23-02-2021

Published online: 12-07-2021

Citation: Roggero Luque JM, Rugolo $M$, Rajchenberg M, Barroetaveña C. Assessment of lignocellulosic residues from Northern Patagonian Andes (Argentina) for cultivation of Pleurotus ostreatus, Universitas Scientiarum, 26(2): 159-177, 2021.

doi: 10.11144/Javeriana.SC262.aolr

Funding: Fondo de Innovación

Tecnológica Regional 007/13.

Electronic supplementary material: n.a

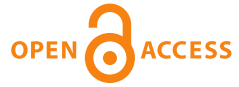

\begin{abstract}
This work evaluated mycelial growth rate $(K r)$ and fruiting of two Pleurotus ostreatus commercial strains $(\mathrm{A} 01,129)$ on formulations composed of lignocellulosic residues from farming and agroindustry of Northern Patagonian Andes, and of woody materials from invasive plants. Rosehip fluffs (RF), rosehip woodchips (RWC), southern beech wood shavings (SBWS), wheat straw (WS), and willow woodchips (WWC) were used as base substrates, and brewing bagasse (BB) as an alternative supplement to wheat bran (WB). $K r$ was higher in WS-WB and WS-BB for both strains. Experiments in fruiting chambers showed biological efficiencies (BEs) above $40 \%$ in WS-BB (both strains) and WS-WB (strain 129). Formulations using RWC or WWC gave BEs under $40 \%$, while those composed of SBWS or RF showed lower $K r$ and contamination by moulds. Medium-scale fruiting experiments using strain A01 showed the highest BEs in WS-BB and RWC-WB. These results suggest that WS is the best substrate for Pleurotus ostreatus culture, although scarce in Northern Patagonian Andes. Nevertheless, WWC and RWC are suggested as alternative substrates, while BB is cheap and abundant, suitable as an alternative supplement to WB.
\end{abstract}

Keywords: Pleurotus ostreatus; Patagonia; edible mushrooms; brewing bagasse

\section{Introduction}

Pleurotus ostreatus (Jacq. ex Fr.) P. Kumm., commonly known as gírgolas or oyster mushrooms in Argentina, is characterized by its ability to grow and produce edible basidiomata in a wide range of temperatures, efficiently degrade a wide variety of lignocellulosic farming, forestry and agro-industrial residues, and shorter cultivation cycles compared to other edible mushrooms [1]. Besides being highly appreciated for their pleasant taste, oyster mushrooms have a high nutritional value, since they are rich in vitamins, proteins, unsaturated fatty acids and minerals such as magnesium, phosphorus, potassium, sodium, zinc, copper, manganese and selenium [2].

In Argentina, oyster mushroom has been commercially cultivated for more than 35 years [3]. In central areas of this country, cultivation is carried out principally in bags using substrates formulated from sunflower seed hulls or wheat straw, which allow an uninterrupted production throughout the year [4]. In Patagonian provinces, specifically Río Negro and Neuquén, cultivation is commonly carried out on poplar trunks (Populus spp.), with seasonal production during autumn and spring months [4]. Poplars are traditionally used as windbreakers, and their wood is currently valued for manufacture of fruit and vegetable boxes and for furniture production. 
Therefore, availability of poplar logs may be limited for edible mushrooms cultivation. In addition, increasing demand for edible mushrooms represents a stimulus for development of new substrate formulations that increase yields using easily available local lignocellulosic wastes.

Edible mushrooms are often grown on unconventional agro-industrial residues, including those obtained from coffee production [5], cotton processing [6] or olive oil extraction [7], and occasionally grown on lignocellulosic material obtained from invasive plant species such as water hyacinth [Eichhornia crassipes (Mart.) Solms] [8]. In the mountain valleys of Argentinian Patagonia located at Neuquén, Río Negro and Chubut provinces, a wide range of agricultural practices are carried out, including small-scale cultivation of cereals for livestock (wheat, oat, barley and rye) [9], as well as agro-industrial activities that include processing rosehip fruits for tea and essential oils and the brewing industry [10]. Barley bagasse is a fiber and protein rich by-product obtained from beer production [11], currently abundant because of growing expansion of this activity throughout this region. It has no or little cost [12] and has already been used as a supplement in mushroom growing formulations in other countries [13]. On the other hand, lenga or southern beech [Nothofagus pumilio (Poepp. et Endl.) Krasser] is one of the most important native forest resources in Patagonia, with 123000 ha of productive forest counted only for Chubut province, that is sawn for sale in national and international markets [14]. By-products obtained from sawing southern beech wood represent abundant forestry residues only in Tierra del Fuego province, that yields approximately $70000 \mathrm{~m}^{3}$ of logs, of which $40 \%\left(28000 \mathrm{~m}^{3}\right)$ represents sawn wood while the remaining $60 \%\left(42000 \mathrm{~m}^{3}\right)$ consists of residues such as sawdust, bark and off-cuts [15]. In Neuquén and Chubut provinces, use of southern beech logs corresponds to $1 \%$ $\left(792 \mathrm{~m}^{3}\right)$ and $17 \%\left(2656 \mathrm{~m}^{3}\right)$, respectively, in relation to the total use of timber species [16]. All these lignocellulosic residues obtained from different activities along west Patagonia provide new opportunities to develop alternative substrates for edible mushroom cultivation based on the assessment of their availability, costs, and chemical compositions.

In addition, rosehip (Rosa rubiginosa L.) and different species of willow (Salix L. spp.) were introduced into Patagonia by European migrants in the late $19^{\text {th }}$ and early $20^{\text {th }}$ centuries $[17,18]$, and represent a threat to native ecosystems because of their invasive behaviour. Their successful spread is a result of their ability to reproduce vegetatively and to occupy highly disturbed environments. Rosehip has spread rapidly through most Andean Patagonian valleys, colonizing forest clearings and open areas created by human activities, as well as sectors of the Patagonian steppe [17]. Its fruits are used to produce jams, teas and liquors by processing the pulp, and to obtain essential oil from the seeds. Residues from rosehip fruits processing includes "fluff", obtained from pulp processing and generally discarded or used as fertilizer, and briquettes, obtained from oil extraction and sold as heating fuel [17]. Willows in Patagonia are principally of Eurasian origin, in particular species and hybrids belonging to $S$. fragilis-S. alba complex [18]. In recent decades, its distribution area has significantly expanded throughout most of the basins of Patagonian rivers in Neuquén, Río Negro and Chubut, covering riverbanks, islands and flood valleys, displacing native species and forming dykes that alter natural dynamics of water courses $[18,19]$. Presence of invasive plants in agricultural lands raises further issues because herbicides and agrochemicals are used for their control or eradication, with potentially negative effects on the environment [17]. Wood of these invasive species, obtained from pruning and removal tasks, would represent a low-cost and widely available substrate for cultivation of edible fungi, and a way to control the spread of these plants.

The aim of the present work was to assess the mycelial growth and biological efficiency of Pleurotus ostreatus (Jacq.) P. Kumm with substrates formulated from lignocellulosic residues available in the Northern Patagonian Andes region. 


\section{Materials and methods}

The experiments were carried out from April to August of 2017 at the Forest Protection Area Laboratories, Centro de Investigación y Extensión Forestal Andino Patagónico (CIEFAP) in Esquel (Chubut Province), Argentina.

\subsection{Mushroom strains}

Two commercial strains of Pleurotus ostreatus available in the study area were used: strain A01 (hereafter, strain A01, Centro PyME-ADENEU, Neuquén, Argentina), and strain CIEFAP 129 from Italy (hereafter, strain 129, Centro de Investigación y Extensión Forestal Andino Patagónico).

\subsection{Materials used}

For mycelial growth and fructification assays, six lignocellulosic materials obtained from four localities within Chubut province, Argentina (Esquel, Trevelin, Aldea Escolar and Lago Puelo) were used: brewing bagasse (BB), rosehip fluff (RF), rosehip woodchips (RWC), southern beech wood shavings (SBWS), wheat straw (WS), and willow woodchips (WWC). These materials were chopped into $1 \mathrm{~cm}$ to $5 \mathrm{~cm}$ pieces and dried in an oven at $65^{\circ} \mathrm{C}$ until constant weight.

\subsection{Chemical analysis}

A $20 \mathrm{~g}$ sample of each residue was milled. The analyses were carried out at the Laboratorio de Análisis Químicos, LANAQUI (CERZOS-CONICET, Bahía Blanca, Argentina), applying a pre-treatment by nitric acid digestion in the Microwave Accelerated Reaction System MARS-5 (CEM Corporation, United States), according to US-EPA method SW-3052 [20]. Determination of total boron $(\mathrm{B})$, calcium $(\mathrm{Ca})$, copper $(\mathrm{Cu})$, iron $(\mathrm{Fe})$, potassium $(\mathrm{K})$, magnesium $(\mathrm{Mg})$, manganese $(\mathrm{Mn})$, sodium $(\mathrm{Na})$, phosphorus $(\mathrm{P})$ and sulphur $(\mathrm{S})$ contents was performed by inductively coupled plasma-optical emission spectrometry (ICP-OES) using the ICPE-9000 spectrometer (Shimadzu Corporation, Japan), according to US-EPA method 200.7 [21]. The semi-micro Kjeldahl method was used to determine total nitrogen $(\mathrm{N})$ content using nitrogen distillation units Büchi, models 316 and K314 (Büchi Corporation, Switzerland). Carbon (C) determinations were carried out using a dry combustion method with the Leco CR-12 Carbon Determinator (Leco Corporation, St. Joseph, Michigan, USA). Metals' quantification was performed by external aqueous calibration methodology using Chem-Lab certified standards patterns, Zedelgem B-8210, Belgium.

Chemical composition of the lignocellulosic residues analysed is summarized in Table 1.

Table 1. Chemical composition of lignocellulosic residues employed in mycelial growth and fructification experiments of Pleurotus ostreatus. BB: brewing bagasse; RF: rosehip fluff; RWC: rosehip woodchips; SBWS: southern beech wood shavings; WS: wheat straw; WWC: willow woodchips.

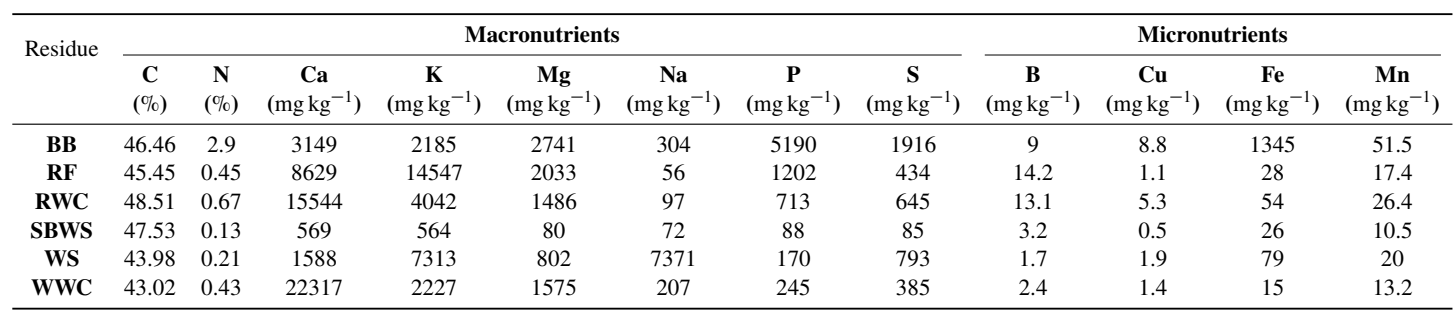




\subsection{Substrate formulation}

Nitrogen content was adjusted to $0.60 \%$ [22] in all formulations using a combination of a base substrate (RF, RWC, SBWS, WS or WWC), a supplement (wheat bran, hereafter WB; BB) and the addition of chemically inert materials (calcium carbonate or calcium sulphate) (Table 2). The nutritional information of WB, specifically its C (42.90\%) and N (2.70\%) contents, was taken from Rugolo et al. [23].

\subsection{Assessment of mycelium growth rate}

Linear mycelial growth was evaluated according to Philippoussis et al. [24]. Glass race tubes (200 mm length $\times 20 \mathrm{~mm}$ internal diameter) were uniformly filled with $10 \mathrm{~g}$ of each formulation (adjusting the moisture content between $56 \%$ and $68 \%$ ), sealed with cotton plugs at both extremes and sterilized in autoclave for $90 \mathrm{~min}$ at $121^{\circ} \mathrm{C}$. After cooling, each tube was inoculated in the laminar flow chamber with one $20 \mathrm{~mm}$ diameter agar disk taken from the periphery of 7-day-old colonies grown on PDA (potato, dextrose and agar) enriched with $5 \%$ poplar sawdust. Three tubes per strain and per formulation were inoculated and then incubated at $24{ }^{\circ} \mathrm{C}$ in the dark.

Mycelial growth was recorded daily, starting the day after inoculation by measuring the progression of the mycelium into the substrate from the inoculation point and by averaging the measurements at four equidistant points around the circumference of each tube. Mycelial growth rate $(K r)$, in terms of $\mathrm{mm} \mathrm{d}^{-1}$, was calculated from the seventh day after inoculation. In addition, the number of days to achieve substrate colonization, or colonization length (CL), was recorded.

\subsection{Fruiting experiments}

\section{Spawn preparation}

Spawn was prepared in $360 \mathrm{cc}$ glass jars half-filled with wheat grains boiled for $20 \mathrm{~min}$ in distilled water and mixed with $2 \%$ calcium sulphate (based on fresh weight basis), sterilized for $90 \mathrm{~min}$ at $121^{\circ} \mathrm{C}$. After cooling, each jar of grains was inoculated by pouring two discs of PDA agar colonized with mycelium and incubated in the dark for 4 weeks at $24^{\circ} \mathrm{C}$.

Table 2. Substrate formulations for mycelial growth and fruiting experiments on strains A01 and 129 of Pleurotus ostreatus. BB: brewing bagasse; RF: rosehip fluff; RWC: rosehip woodchips; SBWS: southern beech wood shavings; WB: wheat bran; WS: wheat straw; WWC: willow woodchips.

\begin{tabular}{ccccc}
\hline Formulation & $\begin{array}{c}\text { Composition } \\
\text { (base substrate + supplement) }\end{array}$ & N (\%) & Humidity (\%) & pH \\
\hline RF-BB & RF (93\%) + BB (7\%) & 0.62 & 62.81 & 6.1 \\
RF-WB & RF (89 \%) + WB (11\%) & 0.62 & 61.3 & 5.77 \\
RWC-BB & RWC (99\%) + BB (1\%) & 0.69 & 55.57 & 6.4 \\
RWC-WB & RWC (99\%) + WB (1\%) & 0.68 & 55.32 & 6.45 \\
SBWS-BB & SBWS (83 \%) + BB (17\%) & 0.6 & 68 & 6.35 \\
SBWS-WB & SBWS (74 \%) + WB (26\%) & 0.62 & 67.32 & 6.16 \\
WS-BB & WS (85 \%)+ BB (15\%) & 0.61 & 67.81 & 6.8 \\
WS-WB & WS (78 \%) + WB (22\%) & 0.6 & 65.01 & 6.58 \\
WWC-BB & WWC (93\%) + BB (7\%) & 0.6 & 66.96 & 6.4 \\
WWC-WB & WWC (89\%) + WB (11\%) & 0.6 & 64.2 & 6.7 \\
\hline
\end{tabular}




\section{Substrate preparation, inoculation and incubation}

All components of each formulation were dry mixed and soaked for 24 hours in distilled water. The excess of water was drained to achieve moisture content from $56 \%$ to $68 \%$ (Table 2). Then, polypropylene bags were filled with $150 \mathrm{~g}$ (on dry weight basis) of each formulation, closed with cotton plugs supported by $5 \mathrm{~cm}$ diameter PVC rings, and autoclaved at $121^{\circ} \mathrm{C}$ for $90 \mathrm{~min}$. After cooling to room temperature, bags were inoculated with $7 \%$ spawn (based on fresh weight of substrate) and incubated in darkness at $24{ }^{\circ} \mathrm{C}$, between $70 \%$ to $80 \%$ room humidity, for 30 days. Each treatment was performed in triplicate.

\section{Cropping, harvest, and determination of BE in fruiting chamber experiment}

After complete colonization stage, bags were transferred to a fruiting chamber (BIOTEC EF105, Pergamino, Argentina) with temperature, humidity, and photoperiod settings. Primordia development was induced by decreasing temperature to $17^{\circ} \mathrm{C}, 12 \mathrm{~h}$ light photoperiod and increasing environmental humidity from $85 \%$ to $95 \%$. To allow the development of primordia, longitudinal cuts were made to the bags, and were watered with distilled water 3 to 4 times a day. When primordia emerged, temperature was increased up to $20^{\circ} \mathrm{C}$, maintaining the same photoperiod and environmental humidity.

Basidiomata were manually harvested once the margins of pilei were slightly convex. The following parameters were recorded for each bag: time period between induction and the first harvest, size, and the weight of basidiomata. Biological efficiency (BE) was calculated using the formula:

$$
\mathrm{BE}(\%)=\frac{\text { fresh weight of basidiomata }}{\text { dry weight of substrate }} \times 100
$$

\section{Medium-scale basidiomata production}

Strain A01, which presented higher growth rate and higher BEs in the different substrates, was selected to scale production on WS, RWC and WWC supplemented with WB or BB and addition of calcium carbonate. The selection of substrates in this stage was based on the yields obtained in fruiting chamber experiments, where SBWS and RF showed low values, added to the fact that the latter was of difficult handling, causing itching and skin irritation to operators. For substrate preparation, the same methodology described above was employed, but bags were filled with $2 \mathrm{~kg}$ of wet substrate (ten replicates by treatment), pasteurized at $80^{\circ} \mathrm{C}$ for two hours. The following parameters were recorded: earliness (period between inoculation of the substrate and formation of primordia), number of flushes, BE (\%) per flush, and total BE (\%).

\subsection{Data analysis}

A factorial design was applied to evaluate mycelium growth rate, with three replicates per treatment (10 formulations and 2 strains). Mean values of $K r$ and CL were evaluated using a complete and balanced two-way ANOVA, partitioned by strains, considering "base substrate" and "supplement" as fixed factors, as well as their interaction. When interaction between factors was not significant, the ANOVA was run again removing the effect of the interaction. Differences between each pair of means were compared using Fisher's LSD post-hoc test. Assumptions of normality (Shapiro-Wilk test) and homoscedasticity (Levene test on absolute values of residues) were tested. $\mathrm{Kr}$ and CL data recorded in race tubes met the normality assumption but showed a slight deviation from the variance homogeneity assumption for both strains. Since ANOVA is 
robust to deviations from this assumption, especially when it involves only fixed factors, large sample size $(n \geq 30)$ and equal number of samples per treatment, this test was performed using untransformed data.

In fruiting chamber experiments, loss of some bags due to mould contamination led to an incomplete and unbalanced factorial design. For each strain, BE and basidiome morphological characters were tested by ANOVA using the General Linear Model procedure in Infostat version 2017 [25], considering "base substrate" and "supplement" as fixed factors. Interaction between these factors was only tested on formulations not discarded by contamination. When one or both formulations sharing the same base substrate were contaminated, those cases were not included in the analysis. When interaction between factors was not significant, the ANOVA was run again removing the effect of the interaction. Differences between each pair of means were evaluated using Fisher's post-hoc LSD test. Comparisons of basidiomata production (in terms of BE) between treatments in the medium-scale experiment were analyzed with ANOVA, followed by Tukey test.

In addition, Spearman correlation analysis was performed to test associations between $\mathrm{BE}, \mathrm{Kr}$, period of time between induction and the first harvest in the fruiting chamber experiment and earliness in medium-scale production experiments using the strain A01.

All statistical analyses were performed using Infostat software version 2017 [25] at a significance level of $5 \%$.

\section{Results}

\subsection{Mycelial growth rate $(K r)$ and colonization length $(C L)$ in race tubes}

$K r$ showed a mean value of $4.14 \mathrm{~mm} \mathrm{~d}^{-1}$ for strain A01 and $3.97 \mathrm{~mm} \mathrm{~d}^{-1}$ for strain 129 . The highest $K r$ values were recorded for formulations WS-WB (strain A01: $5.65 \mathrm{~mm} \mathrm{~d}^{-1}$; strain 129: $5.28 \mathrm{~mm} \mathrm{~d}^{-1}$ ) and WS-BB (strain A01: $5.28 \mathrm{~mm} \mathrm{~d}^{-1}$; strain 129: $4.81 \mathrm{~mm} \mathrm{~d}^{-1}$ ), followed by those composed of RWC (RWC-WB and RWC-BB) and WWC (WWC-WB and WWC-BB) (Table 3). The lowest $K r$ values were recorded for formulations RF-WB (strain A01: $2.33 \mathrm{~mm} \mathrm{~d}^{-1}$; strain 129: $2.38 \mathrm{~mm} \mathrm{~d}^{-1}$ ) and RF-BB (strain A01: $2.14 \mathrm{~mm} \mathrm{~d}^{-1}$; strain 129: $2.38 \mathrm{~mm} \mathrm{~d}^{-1}$ ) (Table 3). $K r$ varied on the different base substrates depending on which supplement was employed in the formulation, and a significant interaction between base substrate and supplement was observed for both strains (strain A01: $F=2.92, P=0.0471$; strain 129: $F=5.38, P=0.0029$ ). Among formulations that shared the same base substrate, differences in $K r$ were significant between formulations SBWS-WB and SBWS-BB (for both strains), and between formulations WS-WB and WS-BB (strain 129 only) (Table 3).

Mycelium CL in race tubes showed a mean value of 18.10 days for strain A01, and 17.83 days for strain 129. The lowest CL was observed in formulations WWC-BB (13.67 days) for strain A01, and RWC-BB (13.33 days) for strain 129, while the highest CL was observed in formulation RF-BB for both strains (A01 strain: 26 days; strain 129: 21.33 days) followed by formulations containing SBWS (Table 3). CL varied between the different base substrates depending on the type of supplement employed only for strain 129 (significant interaction $=2.88, P=0.0494$ ) (non-significant interaction for strain A01: $F=1.35, P=0.2877$ ). For strain 129, differences were significant between formulations RWC-WB and RWC-BB, the latter finishing substrate colonization 2.67 days earlier (Table 3 ). 
Mycelium appearance of Pleurotus ostreatus strains was variable among different formulations. When growing on WWC, mycelium showed a whitish, very dense, and vigorous aspect. A slightly less vigorous appearance, but still whitish and dense mycelium, was observed on SBWS, RF, and WS. In contrast, poor colonization with sparse mycelium was observed on RWC formulations.

\subsection{Fruiting experiments}

Primordia initiation took place earlier for strain A01 than for strain 129. Once settled environmental conditions for basidiomata formation, harvest took place after 4 to 9 days for strain A01, and began after 11 to 22 days for strain 129 .

$\mathrm{BE}$ was low in most of the formulations evaluated in fruiting chamber experiments (Table 4). However, the highest BE values were obtained with WS as base substrate, in formulations WS-BB (72.45\% and $43.55 \%$ for strains A01 and 129, respectively) and WS-WB (43.15\% for strain 129). In contrast, the lowest BE values were obtained in formulations RWC-BB for strain A01 $(8.07 \%)$, and RF-WB for strain 129 (9.63\%). For strain 129, variations in BE were significant only between different base substrates (non-significant interaction: $F=0.60, P=0.6338$ ). For strain A01, BE showed significant differences among some formulations composed by the same base substrate but different supplement $(F=11.09, P=0.0019)$, e.g. WS-BB showed

Table 3. Mycelial growth rate $(K r)$ and colonization length (in days) in race tubes for strains A01 and 129 of Pleurotus ostreatus on different substrate formulations. Results (mean \pm standard deviation) followed by the same letters in the same column and for the same strain showed no statistically significant differences $(\alpha=0.05)$. BB: brewing bagasse; RF: rosehip fluff; RWC: rosehip woodchips; SBWS: southern beech wood shavings; WB: wheat bran; WS: wheat straw; WWC: willow woodchips.

\begin{tabular}{cccc}
\hline Strain & Formulation & Mycelial growth rate $(\boldsymbol{K r})$ & Colonization length days \\
\hline \multirow{4}{*}{ A01 } & $2.14 \pm 0.11^{e}$ & $26.00 \pm 3.00^{a}$ \\
& RF-BB & $2.33 \pm 0.10^{e}$ & $25.00 \pm 2.65^{a}$ \\
& RF-WB & $4.53 \pm 0.22^{b c}$ & $15.00 \pm 0.00^{c d}$ \\
& RWC-BB & $4.72 \pm 0.51^{b}$ & $15.00 \pm 3.00^{c d}$ \\
& RWC-WB & $3.53 \pm 0.25^{d}$ & $21.33 \pm 1.53^{b}$ \\
& SBWS-BB & $4.20 \pm 0.15^{c}$ & $17.33 \pm 0.58^{b}$ \\
& SBWS-WB & $5.28 \pm 0.56^{a}$ & $17.00 \pm 3.61^{c d}$ \\
& WS-BB & $5.65 \pm 0.27^{a}$ & $15.67 \pm 1.15^{c d}$ \\
& WS-WB & $4.72 \pm 0.02^{b}$ & $13.67 \pm 0.58^{d}$ \\
& WWC-BB & $4.27 \pm 0.22^{b c}$ & $15.00 \pm 1.00^{c d}$ \\
\hline WWC-WB & $2.38 \pm 0.41^{g}$ & $21.33 \pm 3.06^{a}$ \\
& RF-BB & $2.38 \pm 0.15^{g}$ & $20.00 \pm 1.00^{a b}$ \\
& RF-WB & $4.78 \pm 0.13^{b}$ & $13.33 \pm 0.58^{e d}$ \\
& RWC-BB & $4.54 \pm 0.08^{b c}$ & $16.00 \pm 0.00^{d}$ \\
& RWC-WB & $3.34 \pm 0.09^{f}$ & $20.33 \pm 0.58^{a b}$ \\
& SBWS-BB & $3.89 \pm 0.06^{e}$ & $18.67 \pm 0.58^{b c}$ \\
& SBWS-WB & $4.81 \pm 0.11^{b}$ & $18.33 \pm 1.53^{b c}$ \\
& WS-BB & $5.28 \pm 0.32^{a}$ & $17.67 \pm 0.58^{c d}$ \\
& WS-WB & $4.29 \pm 0.13^{c d}$ & $16.00 \pm 1.00^{d}$ \\
& WWC-BB & $4.00 \pm 0.21^{d e}$ & $16.67 \pm 1.15^{c d}$ \\
\hline WWC-WB & &
\end{tabular}


a significantly higher BE than WS-WB (Table 4). The culture on SBWS gave different results according to the supplement employed in the formulation. It was not possible to estimate BE in SBWS-BB (shown as NA data, i.e. not available data, in Table 4), since all the bags showed a decline in mycelium colonization for both strains, with patches of substrate without colonization that were subsequently contaminated with moulds of genus Trichoderma during the incubation stage. In contrast, bags containing SBWS supplemented with WB were completely colonized and gave BEs of approximately $20 \%$ for both strains (Table 4). Formulation RF-WB also showed a slow colonization for both strains studied and most of the bags were contaminated during the incubation stage (shown as NA data in Table 4), excepting one bag for strain 129. On the other hand, variability in BE values can be attributed to operative conditions inside fruiting chambers, which showed irregular patterns of environmental relative humidity.

Substrates evaluated in the medium-scale production experiments generally showed less variable $B E$ values than those obtained in fruiting chamber experiments (Table 5). In this respect, formulation WS-BB showed a remarkably lower BE, although RWC (combined with WB or BB) showed higher BEs (Table 4 and Table 5). WS and WWC gave higher BEs when supplemented with BB (25.48 \% and $16.44 \%$, respectively), while RWC showed a higher BE when supplemented with WB (23.60\%). Best earliness values were achieved in WS-BB (51.17 \pm 2.04 days).

No association was observed between $K r$ and the period between induction and first harvest in fruiting chamber experiments (Spearman's test $\rho=-0.18, P=0.25$ ), neither between $K r$ and earliness in medium-scale culture experiments (Spearman's test $\rho=0.06, P=0.91$ ). Also, no association between $K r$ and BE was found (Spearman's test $\rho=0.24, P=0.11$ ).

Table 4. Yield parameters for strains A01 and 129 of Pleurotus ostreatus grown in fruiting chambers on different substrate formulations. Results (mean \pm standard deviation) followed by the same letters in the same column and for the same strain show no statistically significant differences $(\alpha=0.05)$. Values without standard deviation indicate that only one replicate produced mushrooms. Asterisks denote the number of bags discarded by contamination: * (one), ** (two), *** (three). BB: brewing bagasse; RF: rosehip fluff; RWC: rosehip woodchips; SBWS: southern beech wood shavings; WB: wheat bran; WS: wheat straw; WWC: willow woodchips; NA: not available data.

\begin{tabular}{ccccc}
\hline Strain & Formulation & Days between induction and first harvest & Maximum number of flushes & BE $(\%)$ \\
\hline & RF-BB & $7 \pm 0$ & 4 & $39.12 \pm 3.63^{b}$ \\
RF-WB*** & NA & NA & NA \\
& RWC-BB & $7.67 \pm 0.58$ & 2 & $8.07 \pm 2.55^{d}$ \\
RWC-WB & $4.33 \pm 1.53$ & 3 & $9.12 \pm 6.09^{d}$ \\
A01 & NA & NA & $19.56 \pm 8.33^{c d}$ \\
& SBW-BB*** & $6.67 \pm 3.06$ & 2 & $72.45 \pm 8.38^{a}$ \\
& WS-BB & $7 \pm 0$ & 3 & $27.75 \pm 3.27^{b c}$ \\
& WS-WB & $5.33 \pm 1.15$ & 3 & $18.88 \pm 1.90^{c d}$ \\
WWC-BB & $8.67 \pm 1.15$ & 2 & $19.96 \pm 20.94^{c d}$ \\
WWC-WB & $8.67 \pm 3.21$ & 2 & $20.18 \pm 1.34^{b}$ \\
& RF-BB & $11.50 \pm 2.12$ & 2 & $9.63^{b}$ \\
RF-WB** & 14 & 2 & $12.19 \pm 6.82^{b}$ \\
RWC-BB & $16 \pm 141$ & 2 & $14.70 \pm 2.78^{b}$ \\
RWC-WB & $16 \pm 173$ & 3 & NA \\
SBWS-BB*** & NA & NA & $20.89 \pm 4.24^{b}$ \\
SBWS-WB & $15 \pm 173$ & 2 & $43.55 \pm 16.24^{a}$ \\
WS-BB* & $13 \pm 0$ & 2 & $43.15 \pm 2.94^{a}$ \\
WS-WB & $13 \pm 173$ & 3 & $25.07 \pm 6.12^{b}$ \\
WWC-BB & $14.50 \pm 0.71$ & 1 & $18.54 \pm 9.74^{b}$ \\
\hline WWC-WB* & $21.50 \pm 10.51$ & 2 &
\end{tabular}




\subsection{Morphological characters of basidiomata}

For pileus diameter, significant differences were observed only for strain A01 (base substrate: $F=4.72, P=0.0271$; supplement: $F=14.82, P=0.0018$ ). No significant interactions between base substrate and supplement were observed for both strains (strain A01: $F=2.40$, $P=0.1331$; strain 129: $F=1.93, P=0.1946$ ) and formulations composed by the same base substrate showed larger diameter pileus when supplemented with BB than WB. Larger diameter pilei were observed in WS, WWC and RF, all supplemented with BB (Table 6). Smaller diameter pilei were obtained in WS-WB for strain A01 (30.49 mm) and RF-WB for strain $129(36.28 \mathrm{~mm})$.

For stipe length, significant differences were observed at the base substrate level for both strains (strain A01: $F=9.35, P=0.0026$; strain 129: $F=6.72, P=0.0113$ ). For strain A01, differences in stipe length were not dependent of the supplement used in formulations composed by the same base substrate (non-significant interaction, $F=3.62, P=0.0590$ ). For strain 129 , differences were observed only between formulations composed by WS, in which WS-BB showed longer stipes than WS-WB (significant interaction $F=5.07, P=0.0251$ ) (Table 6). Generally, strain A01 showed the longest stipes than strain 129. The shortest stipes were observed in formulations RWC-BB (16.01 mm for strain A01) and RF-BB (17.74 mm for strain A01; $17.59 \mathrm{~mm}$ for strain 129). The longest stipes were obtained in WS-BB for strain A01 (32.58 mm) and WS-WB for strain $129(41.69 \mathrm{~mm})$.

\section{Discussion}

In this work, the analysis of two strains of Pleurotus showed that mycelium growth rate as well as colonization length in race tubes experiments were influenced by the type of residue employed in each substrate formulation. Considering that successful mushroom cultivation is partly due to obtaining high yields in a short time, minimizing length of the colonization stage is of great importance. WWC and RWC showed high $K r$, which were slightly lower than those observed in WS, a commonly used residue in oyster mushroom cultivation $[4,26]$. In contrast, the lower $K r$ in $\mathrm{RF}$ (compared to the remaining residues) can be attributed to the small size of its particles, leading to compaction when moistened. However, despite a lower growth rate, both strains were able to completely colonize this residue in race tubes, suggesting that RF could be used in combination with other residues capable to enhance porosity of the formulation.

Table 5. Yield parameters for strain A01 of Pleurotus ostreatus in medium-scale experiments on selected formulations. Results (mean \pm standard deviation) followed by the same letter in the same column show no statistically significant difference $(\alpha=0.05)$. BB: brewing bagasse; RWC: rosehip woodchips; WB: wheat bran; WS: wheat straw; WWC: willow woodchips.

\begin{tabular}{|c|c|c|c|c|c|c|}
\hline \multirow{2}{*}{ Formulation } & \multirow{2}{*}{ Earliness } & \multirow{2}{*}{ Days to primordial initiation } & \multicolumn{4}{|c|}{ BE $(\%)$} \\
\hline & & & Flush 1 & Flush 2 & Flush 3 & Total \\
\hline RWC-BB & $53.40 \pm 2.30$ & $6-10$ & 15.32 & - & - & $15.32 \pm 6.75^{c d}$ \\
\hline RWC-WB & $53.17 \pm 2.93$ & $6-13$ & 19.84 & 1.9 & 1.87 & $23.60 \pm 7.23^{a b}$ \\
\hline WS-BB & $51.17 \pm 2.04$ & $6-8$ & 17.53 & 6.66 & 1.29 & $25.48 \pm 14.04^{a}$ \\
\hline WS-WB & $55.17 \pm 3.00$ & $6-15$ & 16.9 & 2.51 & 0.44 & $19.84 \pm 10.31^{b c}$ \\
\hline WWC-BB & $53.50 \pm 3.11$ & $6-13$ & 16.44 & - & - & $16.44 \pm 10.63^{c}$ \\
\hline WWC-WB & $54.80 \pm 5.07$ & $6-18$ & 13.46 & 1.03 & - & $14.49 \pm 3.93^{c}$ \\
\hline
\end{tabular}


It has been observed that earliness is favoured in substrates with high mycelial growth rates in cultivation of Pleurotus spp., as well as other species including Volvariella volvacea and Lentinula edodes [1]. This is consistent with medium-scale experiments performed in this work, in which the lowest earliness values were observed on WS substrates, which also showed the highest $\mathrm{Kr}$. On the other hand, no association was observed between the period of time between induction and first harvest in fruiting chamber experiments and $K r$ in race tubes. In this respect, despite RF showed the lowest $K r$ for both strains, the time elapsed between induction and first harvest was similar to remaining formulations under study. Furthermore, it has been observed that early primordia initiation is associated with some characteristics of substrates, including hemicellulose content [24], lower $\mathrm{C} / \mathrm{N}$ and cellulose: lignin ratios [27] and lower $\mathrm{pH}$ [28], which could explain the association between earliness and $K r$.

Also, there was no association between $K r$ and biological efficiency (BE) recorded in fruiting experiments, which is consistent with previous reports in Pleurotus ostreatus cultivation [29] indicating that mycelial growth and mushroom yield have different requirements at different stages of cultivation. It has been suggested that BE should be at least $50 \%$ for a profitable cultivation for Pleurotus species [30]. In this work, the highest BE values were obtained in substrates formulated

Table 6. Basidiomata dimensions for strains A01 and 129 of Pleurotus ostreatus grown on different substrate formulations. Results (mean \pm standard deviation) followed by the same letters in the same column and for the same strain show no statistically significant differences $(\alpha=0.05)$. Values without standard deviation indicate that only one replicate produced mushrooms. BB: brewing bagasse; RF: rosehip fluff; RWC: rosehip woodchips; SBWS: southern beech wood shavings; WB: wheat bran; WS: wheat straw; WWC: willow woodchips; NA: not available data.

\begin{tabular}{cccc}
\hline Strain & Formulation & $\begin{array}{c}\text { Pileus diameter } \\
(\mathbf{m m})\end{array}$ & Stipe length (mm) \\
\hline \multirow{4}{*}{ A01 } & RF-BB & $49.81 \pm 6.49^{a b c}$ & $17.74 \pm 0.89^{c d}$ \\
& RF-WB & NA & NA \\
& RWC-BB & $38.24 \pm 8.47^{c d}$ & $16.01 \pm 2.93^{d}$ \\
& RWC-WB & $32.61 \pm 8.52^{d}$ & $19.96 \pm 1.82^{b c d}$ \\
& SBWS-BB & NA & NA \\
& SBWS-WB & $35.14 \pm 12.25^{d}$ & $23.36 \pm 7.38^{b c d}$ \\
& WS-BB & $55.02 \pm 7.44^{a b}$ & $32.58 \pm 5.55^{a}$ \\
& WS-WB & $30.49 \pm 4.81^{d}$ & $25.87 \pm 2.95^{a b}$ \\
& WWC-BB & $57.20 \pm 5.50^{a}$ & $20.76 \pm 5.17^{b c d}$ \\
& WWC-WB & $42.74 \pm 9.11^{b c d}$ & $24.15 \pm 3.40^{b c}$ \\
\hline \multirow{4}{*}{129} & RF-BB & $40.78 \pm 4.96^{a}$ & $17.59 \pm 1.94^{d}$ \\
& RF-WB & $36.28 \mathrm{a}$ & $25.27 \mathrm{bcd}$ \\
& RWC-BB & $37.36 \pm 1.40^{a}$ & $30.14 \pm 6.35^{b c}$ \\
& RWC-WB & $44.07 \pm 11.28^{a}$ & $21.66 \pm 3.42^{c d}$ \\
& SBWS-BB & NA & NA \\
& SBWS-WB & $49.49 \pm 11.13^{a}$ & $32.34 \pm 7.06^{b}$ \\
& WS-BB & $52.63 \pm 10.40^{a}$ & $28.22 \pm 6.47^{b c d}$ \\
& WS-WB & $45.33 \pm 3.19^{a}$ & $41.69 \pm 5.26^{a}$ \\
& WWC-BB & $54.49 \pm 4.67^{a}$ & $31.23 \pm 1.80^{b c}$ \\
& WWC-WB & $38.90 \pm 2.72^{a}$ & $32.93 \pm 3.58^{a b}$ \\
\hline
\end{tabular}


with WS (up to $43.55 \%$ in strain 129, and up to $72.45 \%$ in strain A01), in accordance with previous reports in this genus $[3,5,31,32]$. It should be noted that although WS is an abundant and low-cost lignocellulosic residue in the Argentine Pampas region [4], it is of limited availability in Patagonia, and is commercialized principally as livestock.

Yield from processing southern beech logs is $33 \%$ in Neuquén and $38 \%$ in Chubut, of which $67 \%$ and $62 \%$ respectively correspond to solid residues and sawdust [16]. Currently, southern beech residues are used for a variety of purposes, including sawdust for chicken and stables litter as well as brick manufacture, while solid residues such as woodchips and shavings are self-consumed by sawmills or sold as fuel [16], all of which reduce its potential availability. Additionally, SBWS do not appear as the first option for Pleurotus cultivation in terms of $\mathrm{Kr}$ and $\mathrm{BE}$, particularly in formulations supplemented with BB. On the other hand, WB is considered a potent inducer of lignocellulolytic enzymes of fungi [33], and probably had a greater stimulating effect on the analysed strains, favouring mycelial growth and degradation of SBWS components compared to BB. Southern beech wood residues could represent an alternative substrate for Pleurotus cultivation in areas where it is widely available, such as Tierra del Fuego province, supplemented with WB. Also, southern beech proves to be a good substrate for shiitake cultivation as demonstrated by Pire et al. [34], who obtained BEs between $20 \%$ and $50 \%$.

The occurrence of Pleurotus naturally growing on fallen or stored willow logs in the northern hemisphere [35, 36], and also in Argentina [37], suggests that it is a suitable wood for growing oyster mushrooms. However, BE observed in WWC formulations were lower than those obtained by Lechner \& Albertó [31] in Salix sp. sawdust supplemented with wheat and oat flour (BEs up to $67.90 \%$ ). Future studies should elucidate the effect of growth conditions, supplement properties and strains used to determine the feasibility of this residue as substrate.

The lowest yields in fruiting chamber experiments were obtained on RWC. Mycelium with very low density was observed in race tubes, which indicates a poorly nutritional or unfavourable environment [38]. It is also possible that lower BEs were due, in part, to the low water holding capacity of this residue (less than $60 \%$, Table 2) and to a higher susceptibility to desiccation of bags, hence affecting basidiomata production. In this respect, medium-scale production experiments (with high environmental humidity) showed no differences in BE between this substrate and WS. This result suggests that use of this highly available local substrate would be feasible and promising if adequate environmental humidity is provided and/or by adding ingredients that increase water holding capacity to the substrate.

In this work, low BE in substrates formulated from willow, southern beech and rosehip woody residues are consistent with results obtained by several authors who employed sawdust or chips for Pleurotus cultivation [39]. Poor performance on these substrates might be attributed to their low nutrient content, low cellulose content, and lower delignification rate compared to other residues, such as wheat straw [39]. Alternatively, increase of BE in these substrates can be achieved through composting, which allows degradation of lignocellulosic components of wood to generate more easily assimilated substances which can facilitate development of fungal mycelium and subsequent fruiting [39].

Basidiomata morphology is an important factor to be considered by Pleurotus producers, which prefer mushrooms with relatively large pileus and short stipe [31, 40], although some specific requirements of packaging and uses incline toward smaller pileus. In the current work, the largest basidiomata were obtained in formulations WWC-BB and WS-BB for both strains and in 
formulation SBWS-WB for strain 129. However, small basidiomata (with less than $5 \mathrm{~cm}$ diameter pilei) were more frequently observed compared to values recorded by other authors for P. ostreatus [31, 39, 41, 42].

Some failures in the management of relative air humidity conditions during the harvest stage could have affected mushroom production and BE in the current work. Even during the humid season (winter months), relative air humidity in Patagonia can be very low in heated rooms. A relative air humidity of approximately $40 \%$ has been recorded in our laboratory facilities. These rigorous conditions could represent a limitation that mushroom producers in the Andean-Patagonian region must overcome to achieve optimal results in growing oyster mushrooms or other species using substrate bags.

Results obtained in this work demonstrate that BB, a low-cost and highly available residue in this region, is suitable as an alternative supplement to WB in oyster mushroom cultivation. Although supplements provide extra nitrogen, their high concentrations can cause a temperature increase in the substrate, leading to mycelium death above $35^{\circ} \mathrm{C}$, as well as an increase in the risk of contamination by competing organisms [43]. Additionally, small particle size of supplements (more noticeable in WB) can lead to substrate compaction if used in large quantities, reducing BE due to poor aeration [44].

\section{Conclusions}

Differential performance of $P$. ostreatus strains on each of the tested substrates offers different alternatives for cultivation in Patagonia. Although the highest BE values were obtained in substrates formulated with WS, abundance and availability of other residues such as RWC and WWC allows the development of suitable formulations for cultivation of this species. Future experiments will be necessary to optimize substrate mixtures containing these residues, as well as environmental conditions during all cultivation stages to increase BE to a profitable scale. Also, cultivation of $P$. ostreatus could be optimized by adjusting techniques such as composting or previous fermentation of the substrate. High availability and low cost of these substrates with low $\mathrm{BE}$ should be subjected to a comprehensive cost/economic analysis of production.

The use of SBWS as substrate could be useful in future experiments for cultivation of species adapted to hardwoods such as Lentinula edodes. In addition, RF could be employed by adjusting substrate formulations, in combination with other components that provide structure and aeration to the substrate mixture.

Our results showed that pileus size was dependent on strains, but also was affected by the supplement, since larger pilei were obtained in formulations with the same base substrate when supplemented with BB. However, since different size preferences can exist regarding to consumption or packaging requirements, this finding suggests that this character could be controlled by choosing the supplements for different base substrates. On the other hand, RWC produced shorter stipes as an added benefit.

Finally, it is recommended to test the performance of a larger number of Pleurotus strains to determine the most suitable ones for cultivation on these substrates. 


\section{Acknowledgements}

This work was supported by grants of Fondo de Innovación Tecnológica Regional 007/13. J.M. Roggero Luque served as a professional consultant hired for the above-mentioned project. M. Rugolo is a post-doctoral fellow co-financed by the National Research Council of Argentina (CONICET) and the Secretary of Science, Technology and Productive Innovation of the Province of Chubut (SCTeIP). M. Rajchenberg and C. Barroetaveña are members of the Career of Scientific Research of CONICET.

\section{Conflict of interest}

The authors declare that there are no conflicts of interest.

\section{References}

[1] Zervakis GI, Koutrotsios G, Katsaris P. Composted versus raw olive mill waste as substrates for the production of medicinal mushrooms: an assessment of selected cultivation and quality parameters, BioMed Research International: 1-13, 2013.

doi: $10.1155 / 2013 / 546830$

[2] Selvi S, Devi PU, Suja S, Murugan S, Chinnaswamy P. Comparison of non-enzymic antioxidant status of fresh and dried form of Pleurotus florida and Calocybe indica, Pakistan Journal of Nutrition, 6: 468-71, 2007.

doi: $10.3923 /$ pjn.2007.468.471

[3] Jaramillo S, Albertó E. Heat treatment of wheat straw by immersion in hot water decreases mushroom yield in Pleurotus ostreatus, Revista Iberoamericana de Micología, 30: 125-129, 2013.

doi: 10.1016/j.riam.2012.11.004

[4] Albertó E, Curvetto N, Deschamps J, González Matute R, Lechner B. Hongos Silvestres y de Cultivo en Argentina: Historia, regiones y sistemas de producción, hongos silvestres de valor económico, consumo, mercado interno y externo, legislación, oferta tecnológica e investigación y desarrollo. In: Martínez-Carrera D, Curvetto N, Sobal M, Morales P, Mora VM, editors. Hacia un desarrollo sostenible del sistema de producción-consumo de los hongos comestibles y medicinales en Latinoamérica: avances y perspectivas en el siglo XXI, chapter 19. Red Latinoamericana de Hongos Comestibles y Medicinales, Puebla: 333-358, 2010 .

[5] Salmones D, Mata G, Waliszewski KN. Comparative culturing of Pleurotus spp. on coffee pulp and wheat straw: biomass production and substrate biodegradation, Bioresource Technology, 96: 537-544, 2005.

doi: 10.1016/j.biortech.2004.06.019

[6] Sardar H, Ali MA, Anjum MA, Nawaz F, Hussain S, Naz S, Karimi SM. Agro-industrial residues influence mineral elements accumulation and nutritional composition of king oyster mushroom (Pleurotus eryngii). Scientia Horticulturae, 225: 327-334, 2017. 
doi: 10.1016/j.scienta.2017.07.010

[7] Rugolo M, Levin L, Lechner B. Flammulina velutipes: an option for "alperujo" use, Revista Iberoamericana de Micología, 33: 242-247, 2016.

doi: 10.1016/j.riam.2015.12.001

[8] Mintesnot B, Ayalew A, Kebede A. Evaluation of biomass of some invasive weed species as substrate for oyster mushroom (Pleurotus spp.) cultivation, Pakistan journal of biological sciences: Pakistan Journal of Biological Sciences, 17: 213-219, 2014.

doi: 10.3923/pjbs.2014.213.219

[9] González AD. Energy and carbon embodied in straw and clay wall blocks produced locally in the Andean Patagonia, Energy and Buildings, 70: 15-22, 2014.

doi: 10.1016/j.enbuild.2013.11.003

[10] Danklmaier C, Heinrichs W, Riveros H. Activación territorial con enfoque de sistemas agroalimentarios localizados (AT-SIAL): la Comarca Andina del Paralelo 42. Argentina, Instituto Interamericano de Cooperación para la Agricultura (IICA), México: 80 pp, 2013.

Retrieved from: http://repositorio.iica.int/bitstream/11324/2636/1/BVE17038715e.pdf

[11] Mussatto SI, Dragone G, Roberto IC. Brewers' spent grain: generation, characteristics and potential applications, Journal of Cereal Science, 43: 1-14, 2006.

doi: $10.1016 / j . j c s .2005 .06 .001$

[12] Wang D, Akiyoshi S, Motoyuki S. Biological efficiency and nutritional value of Pleurotus ostreatus cultivated on spent beer grain, Bioresource Technology, 78: 293-300, 2001.

doi: $10.1016 / \mathrm{s} 0960-8524(01) 00002-5$

[13] Gregori A, vagelj M, Pahor B, Berovi M, Pohleven F. The use of spent brewery grains for Pleurotus ostreatus cultivation and enzyme production, New Biotechnology, 25: 157-161, 2008.

doi: 10.1016/j.nbt.2008.08.003

[14] Carabelli F, Bava J, Momberg F, Cordone V. Estimación de volumen maderable en bosques de Lenga (Nothofagus pumilio) en la región patagónica de Argentina, Bosque, 25: 3-9, 2004.

doi: $10.4067 / \mathrm{s} 0717-92002004000300001$.

[15] Villena P. Capacidad instalada foresto-industrial Tierra del Fuego. Informe sobre las características sectoriales, cadena de producción y costos genéricos mediante relevamiento de las unidades productivas, Programa de Competitividad y gestión sustentable de las cadenas productivas TDF. Tierra del Fuego/BID-Fomin: 35 pp, 2013.

Retrieved from:

https://industria.tierradelfuego.gob.ar/wp-content/uploads/2015/09/INFORME-FINALCAPACIDAD-FORESTO-INDUSTRIAL-2013-TDF.pdf 
[16] Loguercio G, Jovanoski A, Molina J, Pantaenius P. Residuos de biomasa de forestaciones y aserraderos de la región andina de las provincias de Neuquén y Chubut: evaluación preliminar de oferta. Informe final CIEFAP y Secretaria de ambiente y desarrollo sustentable de la Nación, Argentina: 70 pp, 2008.

Retrieved from:

http://www.ing.unp.edu.ar/sede_esquel/pdf/Pantaenius_2008_Residuos_de_biomasa_de_forestaciones_y_aserraderos_en_Neuqu\%C3\%A9n_y_Chubut.pdf

[17] Barros Biscari RM. Los saberes colectivos locales como factores del anclaje territorial. El SIAL de la Rosa Mosqueta rubiginosa de la Patagonia Argentina. In: 116th Seminar "Spatial Dynamics in Agri-food Systems: Implications for Sustainability and Consumer Welfare", European Association of Agricultural Economists. Parma, Italia: 1-9, 2010.

doi: $10.22004 /$ ag.econ.95326

[18] Thomas LK, Mosner E, Leyer I. River dynamics and invasion: distribution patterns of native and invasive woody vegetation at the Río Negro, Argentina, Riparian Ecology and Conservation, 2: 45-57, 2015.

doi: $10.1515 /$ remc-2015-0001

[19] Datri L, Faggi A, Gallo L. Crack willow changing riverine landscapes in Patagonia, Ecohydrology, 10: e1837, 2017.

doi: $10.1002 /$ eco.1837.

[20] U.S. EPA. Microwave assisted acid digestion of siliceous and organically based matrices. Method 3052, Revision 0. In: SW-846. Test methods for evaluating solid waste, physical/chemical methods. Office of Solid Waste, Washington, DC, 1996.

[21] Martin TD, Brockhoff CA, Creed JT. Determination of metals and trace elements in water and wastes by inductively coupled plasma-atomic emission spectrometry. In: Method 200.7, Revision 4.4. Environmental Monitoring Systems Laboratory, Office of Research and Development, US Environmental Protection Agency, Cincinnati, Ohio, USA: 31-72, 1994.

[22] Muez MA, Pardo J. La preparación del substrato. In: Sánchez JE \& Royse DJ, editors. La biología y el cultivo de Pleurotus spp. Limusa, México: 157-186, 2002.

[23] Rugolo M, Lechner B, Mansilla R, Mata G, Rajchenberg M. Evaluation of Pleurotus ostreatus basidiomes production on Pinus sawdust and other agricultural and forestry wastes from Patagonia, Argentina. Maderas, Ciencia y tecnología, 22: 517-526, 2020.

doi: $10.4067 / S 0718-221 X 2020005000410$

[24] Philippoussis AN, Diamantopoulou PA, Zervakis GI. Correlation of the properties of several lignocellulosic substrates to the crop performance of the shiitake mushroom Lentinula edodes, World Journal of Microbiology and Biotechnology, 19: 551-557, 2003.

doi: 10.1023/a:1025100731410

[25] Di Rienzo JA, Casanoves F, Balzarini MG, Gonzalez L, Tablada M, Robledo CW. InfoStat versión 2017. Grupo InfoStat, FCA, Universidad Nacional de Córdoba, Argentina, 2017.

Retrieved from: http://www.infostat.com.ar 
[26] Picornell MR, Pardo-Giménez A, Navarro MJ, Gea FJ. Actualizaciones sobre la preparación del sustrato para cultivar setas Pleurotus spp. In: Sánchez JE, Royse DJ, editors. La biología, el cultivo y las propiedades nutricionales y medicinales de las setas Pleurotus spp. San Cristóbal de Las Casas, Chiapas, México, El Colegio de la Frontera Sur: 83-104, 2017.

[27] Philippoussis A, Diamantopoulou P, Israilides C. Productivity of agricultural residues used for the cultivation of the medicinal fungus Lentinula edodes. International Biodeterioration \& Biodegradation, 59: 216-219, 2007.

doi: 10.1016/j.ibiod.2006.10.007

[28] Gaitán-Hernández R, Salmones D. Uso de residuos lignocelulósicos para optimizar la producción de inóculo y la formación de carpóforos del hongo comestible Lentinula boryana, Revista Mexicana de Ciencias Agrícolas, 6: 1639-1652, 2015.

doi: 10.29312/remexca.v6i7.556.

[29] Curvetto NR, Figlas D, Devalis R, Delmastro S. Growth and productivity of different Pleurotus ostreatus strains on sunflower seed hulls supplemented with $\mathrm{N}-\mathrm{NH} 4^{+}$and/or $\mathrm{Mn}$ (II), Bioresource Technology, 84: 171-176, 2002.

doi: 10.1016/s0960-8524(02)00013-5

[30] Picornell-Buendía MR, Pardo Giménez A, de Juan Valero JA. Reutilización del sustrato degradado de Pleurotus ostreatus. Parámetros cuantitativos. Información Técnica Económica Agraria, 112: 357-374, 2016. doi: 10.12706/itea.2016.022

[31] Lechner BE, Albertó E. Search for new naturally occurring strains of Pleurotus to improve yields. Pleurotus albidus as a novel proposed species for mushroom production, Revista Iberoamericana de Micologia, 28: 148-154, 2011.

doi: 10.1016/j.riam.2010.12.001

[32] Garuba T, Abdukkareem KA, Ibrahim IA, Oyebamiji OI, Shoyooye OA, Ajibade TD. Influence of substrates on the nutritional quality of Pleurotus pulmonarius and Pleurotus ostreatus, Ceylon Journal of Science, 46: 67-74, 2017.

doi: $10.4038 /$ cjs.v46i1.7419

[33] Velu C, Veeramani E, Suntharam S, Kalimuthu K. Insilico screening and comparative study on the effectiveness of textile dye decolourization by crude laccase immobilised alginate encapsulated beads from Pleurotus ostreatus, Journal of Bioprocessing \& Biotechniques, 01: 109, 2011.

doi: $10.4172 / 2155-9821.1000109$

[34] Pire DG, Wright JE, Alberto E. Cultivation of shiitake using sawdust from widely available local woods in Argentina, Micología Aplicada International, 13: 87-91, 2001.

[35] Eslyn WE, Lombard FF. Fungi associated with decayed wood in stored willow and cottonwood logs, Mycologia, 76: 548-550, 1984.

doi: $10.2307 / 3793339$.

[36] Venturella G, Gargano ML, Compagno R. The genus Pleurotus in Italy, Flora Mediterranea 25 (Special Issue): 143-156, 2015. 
doi: 10.7320/flmedit25si.143.

[37] Lechner BE, Wright JE, Albertó E. The genus Pleurotus in Argentina, Mycologia, 96: 845-858, 2004.

doi: $10.2307 / 3762117$

[38] Zervakis G, Philippoussis A, Ioannidou S, Diamantopoulou P. Mycelium growth kinetics and optimal temperature conditions for the cultivation of edible mushroom species on lignocellulosic substrates, Folia Microbiologica, 46: 231-234, 2001.

doi: 10.1007/bf02818539

[39] Girmay Z, Gorems W, Birhanu G, Zewdie S. Growth and yield performance of Pleurotus ostreatus (Jacq. Fr.) Kumm (oyster mushroom) on different substrates, AMB Express, 6: 87, 2016.

doi: 10.1186/s13568-016-0265-1

[40] Li H, Zhang Z, Li M, Li X, Sun Z. Yield, size, nutritional value, and antioxidant activity of oyster mushrooms grown on perilla stalks, Saudi Journal of Biological Sciences, 24: 347-354, 2017.

doi: $10.1016 / j . s j b s .2015 .10 .001$

[41] Ahmed M, Abdullah N, Ahmed KU, Bhuyan MHM. Yield and nutritional composition of oyster mushroom strains newly introduced in Bangladesh, Pesquisa Agropecuária Brasileira, 48: 197-202, 2013.

doi: $10.1590 / \mathrm{s} 0100-204 \times 2013000200010$

[42] Hoa HT, Wang CL, Wang CH. The effects of different substrates on the growth, yield, and nutritional composition of two oyster mushrooms (Pleurotus ostreatus and Pleurotus cystidiosus), Mycobiology, 43: 423-434, 2015.

doi: $10.5941 /$ myco.2015.43.4.423

[43] Fanadzo M, Zireva DT, Dube E, Mashingaidze AB. Evaluation of various substrates and supplements for biological efficiency of Pleurotus sajor-caju and Pleurotus ostreatus, African Journal of Biotechnology, 9: 2756-2761, 2010.

doi: 10.5897/AJB09.1259

[44] Alam N, Amin R, Khair A, Lee TS. Influence of different supplements on the commercial cultivation of milky white mushroom, Mycobiology, 38: 184-188, 2010.

doi: $10.4489 /$ myco.2010.38.3.184 
Evaluación de residuos lignocelulósicos de la región andina de Patagonia norte (Argentina) para cultivo de Pleurotus ostreatus

Resumen: Este trabajo evaluó la tasa de crecimiento micelial $(K r)$ y fructificación de dos cepas comerciales de Pleurotus ostreatus (A01, 129) en formulaciones compuestas de residuos lignocelulósicos de actividades agrícolas y agroindustriales de la región andina de Patagonia norte, y de materiales leñosos de plantas invasoras. Como sustratos base se usaron pelusas de Rosa Mosqueta (RF), astillas de Rosa Mosqueta (RWC), virutas de lenga (SBWS), paja de trigo (WS) y astillas de sauce, y bagazo de cebada cervecera (BB) como un suplemento alternativo al salvado (WB). La $K r$ fue mayor en WS-WB y WS-BB para ambas cepas. Los experimentos en cámaras de fructificación mostraron eficiencias biológicas (BEs) superiores a $40 \%$ en WS-BB (ambas cepas) y WS-WB (cepa 129). Las formulaciones usando RWC o WWC dieron BEs por debajo de $40 \%$, mientras aquellas compuestas de SBWS o RF mostraron baja $K r$ y contaminación por mohos. Los experimentos de fructificación a escala intermedia usando la cepa A01 mostraron las más altas BEs en WS-BB y RWC-WB. Estos resultados sugieren que WS, aunque es escaso en la región andina de Patagonia norte Patagónicos septentrionales, es el mejor sustrato para el cultivo de Pleurotus ostreatus. Aun así, WWC y RWC se sugieren como sustratos alternativos, mientras que BB es barato y abundante, apropiado como suplemento alternativo a WB.

Palabras Clave: Pleurotus ostreatus; Patagonia; hongos comestibles; cebada cervecera.

Avaliação de resíduos lignocelulósicos dos Andes da Patagônia norte (Argentina) para cultivo de Pleurotus ostreatus

Resumo: Este trabalho avaliou a taxa de crescimento micelial $(K r)$ e frutificação de duas cepas comerciais de Pleurotus ostreatus (A01, 129) em formulações compostas de resíduos lignocelulósicos de granjas e da agroindústria dos Andes da Patagônia norte, e de materiais lenhosos de plantas invasoras. Como base para o substrato se utilizaram penugens de Rosa Mosqueta (RF), lascas de madeira de Rosa Mosqueta (RWC), aparas de madeira de lenga (SBWS), palha de trigo (WS) e lascas de madeira de Salgueiro (WWC), e bagaço de cevada da indústria da cerveja (BB) como uma suplementação alternativa à farelo de trigo (WB). A $K r$ foi maior em WS-WB e WS-BB para ambas as cepas. Os experimentos em câmara de frutificação mostraram eficiências biológicas (BEs) superiores ao $40 \% \mathrm{em}$ WS-BB (ambas as cepas) e WS-WB (cepa 129). As formulações usando RWC ou WWC tiveram valores de BEs menores de $40 \%$, enquanto que aquelas compostas por SBWS ou RF mostraram baixa $K r$ e contaminação por mofo. Os experimentos de frutificação à escala intermediária usando a cepa A01 mostraram as mais altas BEs em WS-BB e RWC-WB. Estes resultados sugerem que WS, ainda que seja escassa nos Andes da Patagônia norte, é o melhor substrato para o cultivo de Pleurotus ostreatus. Adicionalmente, WWC e RWC são sugeridos como substratos alternativos, enquanto que BB é barato e abundante, apropriado como suplementação alternativa a WB.

Palavras-chave: Pleurotus ostreatus; Patagônia; fungos comestíveis; bagaço de cevada da indústria da cerveja. 


\section{Maximiliano Rugolo}

Maximiliano Rugolo has a PhD in Biological Sciences (Universidad de Buenos Aires). From 2010 he has focused on cultivation of edible mushroom, and from 2013 to the present he works at the CIEFAP Forest Research Center (Esquel, Patagonia Argentina) with metabolites and enzymes of wild edible mushrooms, their nutritional content and medicinal properties; and cultivation using agro-forestry wastes.

ORCID: 0000-0003-2090-9791

\section{Juan Manuel Roggero Luque}

Juan Manuel Roggero Luque has a B.Sc. and a PhD in Biological Sciences. He has focused on Plant Cytogenetics and Evolution, and worked from 2009 to 2014 and from 2018 to the present at the Instituto de Botánica del Nordeste (Corrientes, Argentina). From 2015 to 2018, he worked at the Centro de Investigación y Extensión Forestal Andino Patagónico (Esquel, Argentina), focusing on the field of Micology and cultivation of edible mushrooms.

ORCID: 0000-0002-9953-7937

\section{Mario Rajchenberg}

Mario Rajchenberg is senior researcher (CONICET), Full Professor (Forest Pathology, Universidad Nacional Patagonia) and Head, Forest Protection, CIEFAP Forest Research Center. He lives and works in Esquel, Patagonia. He is specialist in aphyllophoroid fungi, is passionate of field work, the microscope and collaborative work on taxonomy, phylogeny and forest pathology.

ORCID: 0000-0001-5031-5148

\section{Carolina Barroetaveña}

Carolina Barroetaveña, Researcher at CONICET National Research Council in CIEFAP Forestry Center and Professor at Universidad Nacional de la Patagonia SJB. My research tasks focus on Applied Forest Mycology: mycorrhizae and edible fungi, studding ecology, taxonomy and management of mycorrhizae in plantations and native forests, and phenology, productivity, management, etnomycology and nutritional and nutraceutical properties of wild fungi from Patagonia, fostering their use through mycogastromy, functional food elaboration and mycotourism. I am head of CIEFAP Mushroom Spawn Laboratory

ORCID: 0000-0002-0645-1588 